UDC 811.161. 1'373.23

DOI $10.15421 / 462003$

\title{
COGNITIVE TRANSLATION STRATEGIES (ON THE MATERIAL OF COMIC BOOK “THE DESTINY OF NUMANTIA")
}

\author{
A. Khodorenko \\ Doctor of Philology, Professor, \\ Department of Professional Translation, \\ University of Valladolid, Spain \\ Khodorenko_anna@ua.fm \\ orcid.org/0000-0002-2086-8881
}

Introduction. Since recently, it has been observed a great evolution in the course of the study of comics resulted from the demand of public interest and the necessity to translate comic texts. However, the study of its translation as a form of intersemiotic translation has not been contemplated. Since this field has not been explored, our work aims to contribute to the study of intersemiotic translation in comics, particularly, the comics "Aius. El Destino de Numancia" (Ayus. The Destiny of Numantia). The material of the study is the comic book "Aius. El Destino de Numancia" originally written in Spanish, based on real events that took place in Numancia more than two thousand years ago and tells of the defenders of ancient Numancia, who suffered from the enemies, on the one hand, and those who attacked it, on the other. Ayus, one of the few survivors tells of a 20-year resistance to Rome. The main objectives are as follows: by means of establishing relationships between the information transmitted in the comic (text and image) and the translation to define main translation strategies used. Therefore, the present work consists of an analysis of the SL of comics and its translation into Russian, considering types of translation difficulties and problem solving ways, i.e. appropriate strategies of translation.

Methods and methodology of investigation. After analyzing methods, strategies and techniques of translation we came to the following results: It has been used the method of equivalent literary translation. Among techniques of translation, we define the following ones: adaptation, linguistic extension, amplification, compensationlinguistic description, elision, equivalent (close equivalent), generalization, modulation, particularization (specification), borrowing, literal translation, transposition. The theoretical background of the present article ows to the works of (Obolenskaya, 2006; Ortega y Gasset, 1984; Newmark, 1988; Lvóvskaya, 1997).

Results and discussion. The phenomenon of lacunarity has been described as a key source of translation problems. And problems solving metnods have been suggested. Cognitive metaphor is thoroughly explained and depicted by J. Lakoff (Lakoff, 1986). "Our consciousness is metaphorical in its essence", said J. Lakoff in his work, "The Metaphors We Live by". Consciously and subconsciously, a person is in the process of cognizing the world, linguistic units as a product of cognitive activity. J. Lakoff insists and proves that we perceive the world by the types of cognitive models, and one of these models is a metaphorical perception of reality. We accept the theory of J. Lakoff, and for him we consider the metaphorical model of perception of reality by the example of language units. According to J. Lakoff, metaphor is a complex of linguistic means, systemic means of redistribution of the field of application of the concept" (Lakoff, 1986: 26). We agree with the term cognitive metaphor and use the following definition. The cognitive metaphor is a redistribution of signs of objects or phenomena from one sphere of knowledge to another, which is based on the individual cognitive style of the author of the expression.

The phenomenon of cognitive metaphor is inherent in any language: English, Russian. Usually a metaphor considers the transfer of a sign of an object or phenomenon to another subject or phenomenon. For example, we encounter: ... He de acabar con algunas revueltas de pequeñas tribus en el sur... $\rightarrow$ Я должен закончить некоторые дела на юге...Dómine, ¿Mañana partimos 


\section{Ukrainian sense. 2020. ISSN 2313-4437}

ya? Acabamos de llegar... $\rightarrow$ Mbl уезжаем завтра же? Мы только что прибыли ... ¡ґСаlla esclavo!! $\rightarrow$ Молчать, раб! ....

Studies devoted to the processes of metaphorization are based on the studies of lexicology, sociolinguistics, and pragmatics. A contextual orientational metaphor in the terminology of J. Lakoff and metaphorization is a complex linguistic, social and cognitive phenomenon. For example below, we encounter orientational metaphor. A sólo dos manzanas de esta casa estaba la ті́a. $\rightarrow$ Два квартала от этого дома были моими.

Lo recuerdo como si fuera ayer y ya hace casi medio siglo... $\rightarrow$ Я помню все, как будто это было вчера, ...почти полвека назад ...The softening names are determined from the ancient rhetoric, the term cognitive metaphor, whose function is to reflect the reality and translate it into linguistic forms that can affect the recipients.

Language is proved to be closely connected with mentality, culture, traditions of its carriers, and therefore many processes and phenomena that occur in society are reflected in the language system. English as one of the most dynamically developing languages of the world has undergone significant changes over the last decade, which are largely determined by changes in the social sphere. The main types of cognitive metaphor (according to J. Lakoff are: 1. Metaphor-comparison. 2. Orientation metaphor. 3. Ontological. 4. Communication channel metaphor. 5. Concept metaphor (conceptual). Below, we will return to these types of metaphors and give examples of each of them, with the exception of the type of communication channel metaphor. In our actual material, we identified 4 types of metaphors, as illustrated in the table. We formulate a definition that reflects the meaning of all definitions of the cognitive metaphor, given above. The cognitive metaphor is a redistribution of signs of objects or phenomena from one sphere of knowledge to another, which is based on the individual cognitive style of the author of the expression. Summing up all the above, we can conclude that the metaphor fulfills the functions of knowing reality. According to J. Lakoff, "thinking is metaphorical in its essence". In this case, an assessment of the speaker of the subject of speech as such. In this case, the selection of speakers of such signs, which are not just called, but try to cover up deeper and open the essence of the phenomenon from the position of the speaker. The views of philologists are different in terms of linguistic means and methods of creating a metaphor (cognitive metaphor), and the translation of this phenomenon. It should be noted that they are not contradictory but complementing one other. Among them, the following translation is often used: 1) words with fuzzy semantics (some, proper, etc.); 2) nouns with a fairly general meaning, used for naming entirely specific objects and actions (action, product, object, product, product, material, signal). 3) pronouns, 4) verbal forms. It is important to study not only the ways of forming a cognitive metaphor, but the methods of translation of the metaphor and to characterize the general principle of their translation on our factual material. To do this, it is necessary to turn to the poetic translation, the basic principle of translation, the concept of equivalence when displaying the meaning.

It can be found in the reflection of the functional-situational and ironic content of the original. The aesthetic function of the language of the work of art is revealed in its submission to the artistic design of the writer, his general aesthetic guideline. They determine the principles and methods of selecting the author of linguistic units among other synonymous means of expressing figurative content. The language of the text involves the use of the linguistic units estimated as stylistically colored. Sometimes their absence in cases where they are motivated, is perceived even as a violation of the literary style. Consequently, deviation from the norm at the level of the linguistic units may, under certain conditions, be the norm of the organization of artistic text. Artistically justified conformity of the choice and organization of linguistic means of author's images - this is a specific style of the author, which in our case is the typical cognitive metaphor that it builds. In the style of the comic, the linguistic elements of all functional varieties of language are combined, and this together with the individual word-making contributes to the construction of the artistic image (images) of the hero, gathered together in the story. The spoken elements (both neutral and emotionally expressive) in the artistic text acquire additional shades, because the semantics of the word here "acts in its general form (the selection of these tokens, their 


\section{Ukrainian sense. 2020. ISSN 2313-4437}

combination, the general tone of presentation, figurative means used throughout the text array, the author's style of narration - all this imprints on the quality of emotionally-expressive color of the word)". Among the emotionally-expressive groups of spoken vocabulary, which are widely used in the language of artistic works, especially for the purpose of linguistic characterization of characters, a group of words is stylistically reduced. But the norm of such a vocabulary is limited to a certain style, since normative in the stylistic aspect can be considered as a property inherent in this style. The degree of expressiveness can not be recognized as a criterio for attributing the word to nonnormative ones, since words are emotionally-evaluative, as well as rude, vulgar, familiar, etc., on the terms of use, are identical to non-expressive words, inherent in uncommitted communication. Involvement of the cognitive metaphor in the language of the character contributes not only to the more complete disclosure of the content of the statement, but also to the reproduction of the subject of speech, his social and individual characteristics. All this, together with the use of other expressive means, makes it possible for an individual-stylistic variation within the limits of the linguistic norm, the creation of a stylistically expressive, deprived monotony of the narrative. Consequently, the norms of the literary language allow the use in the style with a certain expressive purpose of both normative and non-normative elements of spoken language, in particular the cognitive metaphor. The use of cognitive metaphor in the language of fiction is not just and not always an adequate reflection of live spoken language, which is, as a rule, its stylization, which can be embodied in different ways, acting as one of the means of perceiving reality by the native speaker. The admissibility of using in literary texts non-normative in terms of the general literary norm of the linguistic units causes the problem of establishing a certain limit in their use, the greater the role of the cognitive metaphor in creating emotional load in the artistic original text and its translation. It is clear that artistic text can not be evaluated solely from the standpoint of normative dictionaries and grammar and translation norms. But, on the other hand, it's erroneous to assume that the writer or translator does not adhere to any norms, because each era, every literary direction has its own rules of organization of artistic text. The language of literature is fundamentally different, it can not be locked within a particular language style, especially given that the language of a particular artistic work is a whole system of styles and stylistic contexts. Here is an example where we observe the interference of cognitive styles in the process of reproduction of the metaphor in the original and translation... De haber matado a su abuelo Balor con su honda, daba paso a la oscuridad de la noche... $\rightarrow$... Убив своего деда Балора, он уступил место темноте ночи ... In the Russian translation we propose the replacement of the lexical unit in expressive and stylistic terms. Such a replacement completely reproduces a cognitive metaphor (daba paso a la oscuridadуступил место темноте ночи). The close interaction and association of different in expressive and stylistic terms of lexeme contributes to the consolidation of a significant layer of vocabulary of spoken origin in written use, which leads to the expansion of the composition of the literary language. The expediency of using spoken units in the language of artistic works is determined by the author's idea, and, if artistic motivation, the components of a spoken language that are outside the general literary norm may well be included in a specific text. In the translation process it often becomes impossible to use the matching words and phrases provided by the dictionary. In such cases, we resort to a transformational translation, which consists in transforming the internal form of a word or phrase, or in its complete replacement, to adequately convey the content of the statement. It is difficult to translate the cognitive metaphor, the transfer of comic in interlingual communication, since, as it was noted, metaphor is a linguocultural and cognitive-discursive phenomenon, that is, the perception of a cognitive metaphor is different in native speakers and recipients of translation, moreover, the success of the translation of a metaphor depends on individual cognitive features, background knowledge of the translator and the recipient. For our work, it is important to identify the main features of the creation of the equivalence and adequacy of the translation of the cognitive metaphor in the situation of poetic translation, in particular the translation of the cognitive metaphor of the works of the comic. One of the main tasks of the translator is to maximally transfer the contents of the original, and, as a rule, the actual commonality of the content of the original and translation is very significant. In modern translation 


\section{Ukrainian sense. 2020. ISSN 2313-4437}

studies, we can find three basic approaches to the definition of equivalent. Some definitions of translation actually replace equivalence with identity, arguing that the translation must fully retain the original content. The solution of the problem of translation equivalence consists in an attempt to find in the contents of the original some kind of invariant part, the preservation of which is necessary and sufficient for the achievement of the equivalence of translation. In other words, if the translation can perform the same function or describes the same reality, it is equivalent. In equivalence, the theory of translation should be understood to preserve the relative equality of content, content, semantic, stylistic and functional - communicative information contained in the original and translation. It is worth emphasizing that the equivalence of the original and the translation is primarily, i.e. the cognitive metaphor must be preserved in translation. The problem with the equivalent translation of the comic, where the author demonstrates complex and profound erudition in cultural values, knowledge of history and ridicule of ignorance. The comic has not only national characteristics, which are also manifested in the choice of its subject, as well as in the specificity of creating a laughing effect. English irony is often rated as too specific to always be understood by representatives of other peoples. However, much of it is the result of various factors - from insufficient background knowledge to incorrect translation. The study of the true peculiarities of irony in the context of ethno-cultural specificity and its pseudo-peculiarities, simulated by misunderstandings as a result of communication failure, has at the same time the general theoretical and practical significance, gaining special relevance in connection with the urgent need for developing adequate communication. It is necessary to combine the achievements of philosophical (theoretical study of comic) and philological (the connection of language and culture in general, and the theory of translation in particular) of disciplines. The same situation can be described due to different combinations of peculiarities inherent to it. As a consequence of this, there is the possibility and need to identify the situations described from different sides. The language contains sets of statements that are perceived by speakers of the language as synonymous (meaning the same thing), despite the complete discrepancy between the components of their linguistic means. The cognitive metaphor used by heroes of the narrative highlights not only objective but also subjective reality around heroes, and depicts reality through the prism of the author's perception of this extra-ordinary reality. What is interesting is the cognitive style of thinking and, as a result, the language of the narrative. Cognition of the world becomes closer to the perception of the world of heroes. In this we see the mystery of the virtuosity of literary craftsmanship. Below, there are given examples of original statements, corresponding words with a missing trop, Russian translations, as well as translation strategies used in translation. Types of metaphors and the examples with the original metaphor and the Russian translation with preserverd metaphors are given below. 1. Cognitive metaphor acccording to G. Lakoff borrows from the natural language allusions, appealing to the associations and individual image perception. Al llegar, sometió al ejército a un duro entrenamiento. Desterró a criados, mercaderes, rameras, adivinos y agoreros. Vendió carros, mulas y equipajes, conservando sólo lo imprescindible... $\rightarrow$ Когда он приехал, сурово тренировал солдат; слуги, торговиьы, проститутки, гадалки были выдворены. Он продал все, сохраняя только предметы первой необходимости ...El destructor de Cartago $\rightarrow$ Разрушитель Карфагена ... Tanto nos temía roma que nos "obsequió" con su mejor general: Publio Cornelio Escipión Emiliano. $\rightarrow$ До сих пор Рим боялся, что он “отблагодарит” нас своим лучшим генералом: Публий Корнелиус Сципио Эмилиан. Rоzaтоs con los dedos la gloria de los dioses... $\rightarrow$ Mbl почти коснулись пальцами славы богов. 2. Conceptual metaphor borrows concepts from other fields of science, for example from medicine, as in the examples below. Es un disparate aventurarse por cosas leves. Es imprudente el general que entra en acción sin necesidad, así como excelente es el que se arriesga cuando la ocasión lo pide: así es que los médicos no usan sajaduras ni cauterios antes de las medicinas. $\rightarrow$ Безумие рисковать ради мелочей. Генерал, который вступает в бой без необходимости, действует неосмотрительно. Надо рисковать, когда дело требует этого, как и врачи не используют прижигание, прежде чем разобраться в лечении. No quería luchar ni pactar una tregua... $\rightarrow$ Я не хотел ни сражаться ни соглашаться на перемирие Onuestra rendición incondicional o 


\section{Ukrainian sense. 2020. ISSN 2313-4437}

nuеstra mиеrte. $\rightarrow$ Или наша безоговорочная капитуляция или наша смерть. La ciudad fue arrasada, destruida de raíz... $\rightarrow$ Город был опустошен, разрушен до основания. 3. Metaphor of comparison operates conjunctions to create the image base don the difference between two or more compared objects. Nuestras constantes emboscadas le hicieron malograrse y temeroso de la guerra como era y de ser llamado a rendir cuentas en roma, pactó secretamente con nosotros el fin de la guerra: un tratado que, ya en roma y a salvo, Pompeyo negó haber establecido. $\rightarrow$ Hauu постоянные засады сломали его и он заключил с нами секретный договор, чтобы положить конеи войне: договор, от которого, в Риме, Помпей отрекся. 4. Orientational metaphor uses indications of places and time, action to create the images and make them more intense. Marco Popilio Laenas, el inútil que quiso vencernos sin honor ... $\rightarrow$ Маркус Попилюс Лэнас, никчемный, без чести, хотел победить нас. Quién, con unas tropas ya mermadas, nos intentó cercar... $\rightarrow$... Кто, войсками, пытался нас окружить. Nada quе el tieтро по pueda solucionar... $\rightarrow$ Время покажет... No lo llegué a entender jamás... $\rightarrow$ Я никогда не мог понять Tú vienes de roma ahora. Dime, ¿qué gladiador es el más famoso en estos momentos? $\rightarrow$ Bы пришли из Рима. Скажи, какой гладиатор сейчас самый знаменитый? El valor que me otorgan los romanos como esclavo no es debido a mi servicio ni a mi apariencia. $\rightarrow$ To, что римляне относятся ко мне как к рабу, не связано с моей службой или моей внешностью.

The state of modern art clearly indicates the development of certain trends that can be characterized as processes of poetic translation, understanding the concept of translation in the general artistic dimension. For a more precise definition of this notion in this context, terminological upbringing is introduced, which focuses attention on specific interactions between different types of artistic creativity. Poetic translation covers a wide range of different phenomena, screening and staging of literary and prose works, book illustrations and easels - graphic or pictorial - cycles created on literary themes, certain samples of ballet and pantomime, software music, cinema operators, musicals, even photos novels and comics that sometimes can act as a primary source in the process of poetic translation. Most of these phenomena are often referred to as the category of so-called interpretations in art; sometimes certain kinds of them are called intermediate phenomena of culture, manifestations of mass culture, and so on. We believe that today there are necessary precursors for combining all these phenomena into one conceptual whole. The term "transformation" in translation studies is used to show the relationship between the source and the end language expressions, the replacement in the translation process of one form of expression by another, the replacement, which we call transformation or transformation figuratively. Thus, the following operations (translation transformations) are operations of redefining content. There are different points of view regarding the division of transformations into species, but most authors converge in one, that the main types of transformations - they are grammatical and lexical. In turn, these transformations are divided into subspecies. In lexical systems of the languages there are differences, which are manifested in the type of semantic structure of the word. Any word, that is, lexical unit, is part of the lexical system of language. This explains the peculiarity of the semantic structure of words in different languages. Therefore, the essence of lexical transformations consists in the replacement of lexical units (words and constant phrases) of the source language by lexical units of the target language, which are not their vocabulary equivalents and have a different meaning than the one transmitted by them in the translation of the source language unit. It is not always possible to clearly define lexical transformations because they are often interconnected. In general, it is possible to distinguish the following main varieties of lexical transformations: specification is the replacement of a word or phrase of a source language with a broader meaning in a word or phrase of a target language with a more narrow meaning. Typically, the vocabulary of the Russian language is characterized by greater specificity than the corresponding lexical units of the English language. This has been repeatedly noted by linguists. Specificization can be linguistic and contextual. In linguistic concretization, the replacement of a word with a broad meaning in a word with a more narrow meaning is conditioned by differences in the composition of two languages - or the absence in the target language of a lexical unit that has the same broad meaning as the unit of 


\section{Ukrainian sense. 2020. ISSN 2313-4437}

the source language or differences in their stylistic characteristics, or the requirements of the grammatical order (the need for the syntactic transformation of the sentence, in particular, the replacement of the verbal verbal sentence). For example, Cuando al caer la tarde, lug cien veces mayor, y con gran estruendo por el recuerdo... $\rightarrow$ B сумерках все меняется и кажется другим...nриходят воспоминая. Generalization is the reception of the opposite of concretization, because it consists in replacing the particle with the generic, species-specific concept of generic. When translated from English into Russian, it is used much less often than specification. This is due to the peculiarity of English vocabulary. The words of this language are more abstract in nature than Russian words related to the same notion. Adoption of lexical addition - both lexical and grammatical transformations often require the addition of additional words. The introduction of additional words is due to a number of reasons: the differences in the structure of the proposal and the fact that more compressed English suggestions require a more comprehensive expression of thought in the Russian language. The absence of a corresponding word or corresponding lexicalsemantic variant of a given word is also the reason for the introduction of additional words in the translation. Hacía varias lunas, llegaron a Numancia cerca de doce mil segedenses pidiendo nиеstra ayuda. $\rightarrow$ Несколько времени тому назад около двенадиати тысяч сегедейцев прибыли в Нумансию с просьбой о нашей помощи. Habian incumplido unos antiguos tratados firmados tras la gran batalla de mons caunus. $\rightarrow$ Они нарушили некоторые старые договоры, подписанные после великой битвы в Монсе Чоунус. Roma les había declarado enemigos de la república. $\rightarrow$ Рим объявил их врагами Республики. Sabiendo quе los aniquilarían, abandonaron su ciudad y huyeron hasta aquí. $\rightarrow$ Зная, что они будут уничтожены, они покинули свой город и скрылись здесь. Gracias a su caudillo, Caros, el más belicoso de los guerreros, con buenas dotes de mando y famoso por su valor, los numantinos acogimos a su pueblo. Y no sólo sus almas, sino también sus problemas con Roma. $\rightarrow$ Благодаря своему лидеру, Каросу, самому агрессивному из воинов, с хорошими лидерскими качествами известному своей храбростью, нумантинщь приветствовали его в своей деревне. И не только народ, но и борьбу с Римом. Omission is a phenomenon that is exactly the opposite of addition. In the translation, the most commonly used words are semantically redundant in terms of their semantic content. One example of redundancy is the use of synonyms for all the styles the English language. In Russian, it is not perfectly true, therefore, in the case of translation for these cases, it is necessary to use omission (that is, not to repeat the synonym - replacing two words with one). A semantic development is used to substitute corresponding vocabulary unit in the translation of a contextually close variant, lexically related to it. These include metaphor and metonymy. Perder esa batalla fue muy duro, pero reconoced que, bajo los pactos de Graco, no hemos vivido tan mal durante estos años y nos han ... $\rightarrow$ Потеря была очень тяжелой, но признаем, что в соответствии с пактами Гракха мы прожсили эти годы...Pactos que, por otra parte, nos han exprimido ya bastante. $\rightarrow$ Ho, с другой стороны, нас достаточно унижали. Esos pagos abusivos de Saghums y plata nos hacen trabajo duro sólo para ellos. Cada año vemos cómo nuestros jóvenes, obligados por los pactos, parten como mercenarios a luchar en sus ejércitos y la mayoría no regresa jamás. $\rightarrow$ Эти непомерные платежи и поборы, мы должны были много работать чтобы просто оплатить их. Каждый год молодые люди, вынужденные платить непомерные налоги, уходят сражаться наемниками в армиях, а большинство никогда не возвращается. Lexical compensation can be defined as compensation of the part of the missing meaning of a translated lexical unit. It can be expressed or realized by means of TL corresponding phraseological units. A tu padre no le falta razón, Aius... $\rightarrow$ Tвой omeu не ошибается, Aйус ...¿ ¿ te parece poco? Creo firmemente que debemos renegociar unos nuevos tratados con los romanos que nos permitan continuar con nuestras vidas en estas tierras. $\rightarrow$ Иэто кажется мальм. Я твердо верю, что мы должны пересмотреть новые договоры с римлянами, которые будут продолжать позволять нам жить на этих землях. 4.000 numantinos rendimos a 20.000 romanos comandados por un plebeyo, temerosos ante el rumor de que refuerzos de los pueblos cántabros iban a llegar a Numancia. $\rightarrow 4000$ нумантийцев побороли 20000 римлян, которым командовала каббала плебеев, опасаясь слуха о том, что 


\section{Ukrainian sense. 2020. ISSN 2313-4437}

подкрепления из деревень Кантабрии достигнут Нумансии. Y еso fue más de lo que roma podía digerir. $\rightarrow$ И это было больше, чем Рим мог переварить. Cото castigo, el senado humilló a Mancino entregándonoslo en una ceremonia bochornosa. $\rightarrow$ В качестве наказания Сенат унизил Мансинуса, предав его позорной церемонии. Pero no lo aceptamos...El hombre era digno, pero el general fue el más desgraciado de todos los romanos. $\rightarrow$ Но мы не приняли его ... Он был достойным человеком, самым безнадежным генералом из всех римлян. А реsаr de quе nos superaban en una proporción de ocho a uno, resistimos una y otra vez sus ataques, durante veinte años. $\rightarrow$ Несмотря на то, что они превосходили нас (восемь против одного), мьь сопротивлялись их атакам снова и снова в течение двадиати лет.

According to the results of the consideration of various metaphors of the comic and the means of translation of metaphors, we can say that the translation option should provide the same associative ties that the pictorial tool has in the original text in order to as accurately as possible transmit all the slightest shades of meaning. Thus, the most accurate reproduction of a metaphor in a work of art is one of the important conditions for the creation of its adequate translation. According to the research objectives analysis of extralinguistic factors, iconic code and translation transformations made it possible to define and clarify the notion of cognitive metaphor through knowledge of the context of the work, knowledge of culture, traditions, etc. They can be expressed in the form of phraseologisms. The phenomenon of the equivalence of the translation of the cognitive metaphor was analyzed in general terms according to the peculiarities of the translation. A comparative analysis has shown that the difficulties that have emerged throughout the work are due to the fact that grammatical and lexical forms are not equivalent to Russian ones. Numerous phraseologisms were also a problem in translation, so they were replaced by similar Russian ones.

Although the comic is a very open genre in terms of its structure, the one analyzed here in Numancia presents some particular characteristics in comparison with others.

First, in terms of the macrostructure of this comic, it corresponds to a book format and a bulletin organization per page, unlike most of the texts belonging to this genre, which usually group several vignettes and where they even dedicate a different space to each one on each page. In this way, each vignette is given a considerable and equal importance to the rest of the vignettes. As for the macro units, we have already said that the format of the bullet is one page and it is always the same, although its representation varies. This vignette does not have an element that frames it habitually, with which we can say that simplicity is also present in the design of this and we only see how some elements of the drawing frame a special area of the image in some occasions. In its composition, we can see that the text is integrated into the image although, it is not included in any iconographic element. Usually, the image is given more space and a more privileged place.

Conclusions. Throughout this work we have seen that the evolution of the comic has been since the last century and that in recent years has reached its peak and has diversified in terms of theme, public and subgenres. In general terms we have observed that the demand for comics is growing as is the interest in the study of this type of text. Although there has been a lot of progress in the study of the comic from the perspective of its composition and as a pedagogical tool, the study of this type of texts as a transmitter of the faith is little explored, which is why we have started this research. In the present work we have analyzed this type of translation that has come to be called subordinated because it occurs between two different codes, visual and written, giving rise to what Roman Jakocbson considered an intersemiotic translation. In this type of texts we have semiotic verbal and non-verbal systems that interact and complete each other. We also had the interest to contribute to the study of semiotic relationships and the use of signs that are observed in our particular example, providing a classification of them and detailing those found in the examples of the corpus. This knowledge will contribute to a better performance of the interlinguistic and intralinguistic translation exercise. On the other hand, we have exposed the relevance of the figure of Warrior of Numancia within the comic book genre in the Numancia for the need to spread knowledge about legendary heroism. 


\section{REFERENCES}

Albakry, M. (2004). Linguistic and cultural issues in literary translation. Translation Journal, 8 (3), 161-172.

Aparici, R. (1992). Cómic y fotonovela en el aula. Madrid: Ediciones de la Torre.

Barbieri, D. (1993). Los lenguajes del cómic. Barcelona: Paidós.

Eco, U. (1993). Lector in fabula. La cooperación narrativa en el texto narrativo. Barcelona: Lumen.

Garcia, R. (2017). El destino de Numancia - Aius, Numanguerrix aporta este cómic en Numancia 2017. Elige Soria. Retrieved from: https:/elige.soria.es/el-destino-de-numancia-aiusnumanguerrix-aporta-este-comic-en-numancia-2017.

Lakoff, J., \& Johnson, M. (2003). Metaphors we live. London: The university of Chicago press.

Lakoff, J. (1987). Women, Fire, and Dangerous Things: What Categories Reveal About the Mind. London: The university of Chicago press.

Lvóvskaya, Z. (1997). Problemas actuales de la traducción. Granada: Método Ediciones.

Newmark, P. (1988a). A Textbook of Translation. Hertfordshire: Prentice Hall.

Newmark, P. (1988b). Approaches to Translation. Hertfordshire: Prentice Hall.

Newmark, P. (1991). About Translation: Multilingual Matters. Clevedon, Philadelphia, Adelaide: Multilingual Matters Ltd.

Nida, E. A. (1964). Towards a science of translation, with special reference to principles and procedures involved in Bible translating. Leiden: Brill.

Obolenskaya, Y. L. (2006). Hudozhestvennyj perevod i mezhkul'turnaja kommunikacija [Literary translation and intercultural communication]. Moscow: Gnozis [in Russian].

Ortega y Gasset, J. (1984). España invertebrada. Madrid: Espasa-Calpe.

Paramio, L. (1971). El cómic y la industria cultural. Estudios de Información, 19-20, 169194.

Pierce, Ch. S. (1987). Obra lógico-semántica. Madrid: Taurus.

\section{Анотація}

Постановка проблеми. Увагу в статті зосереджено на проблемах стратегій перекладу загалом та аспекті когнітивного перекладу метафори зокрема, інтерсеміотичному перекладі коміксів “EEl Destino de Nuтаnсіа (Аюс. Доля Нумантіі)” іспанської на російську мову.

Мета статті. Обговорити та проаналізувати складнощі перекладу, переважно стилістичні, когнітивні, культурні конфлікти в процесі перекладу.

Методи дослідження. Матеріал дослідження уточнено методами опису та аналітичного спостереження за процесом вирішення проблем у процесі перекладу.

Основні результати дослідження. Матеріалом статті $\epsilon$ переклад іспанського коміксу, заснованого на реальній історії Нумантії, історичній боротьбі з експансією Риму під проводом жителів Нумантії, сучасної території Кастилії та Леона, Іспанія. Проблему еквівалентності схарактеризовано в загальних рисах та згідно з основними концепціями теорії та практики перекладу. На основі виявлених типологічних характеристик, типів, компонентів, функиій мови джерела була побудована найчастіше використовувана модель вирішення проблем та висвітлено найуживаніші стратегії перекладу, а також рекомендовано вирімення проблеми лакунарності, проблем перекладу складних асиметричних конструкцій, надано перекладаџькі рішення.

Висновки та перспективи. Обтрунтовано емоційно-когнітивний компонент, значення міжкультурної адаптачії в межах евристичної теорії в прочесі подальшого розвитку теорії та практики професійного перекладу. Викладено перспективи поточного дослідження з охопленням когнітивного компонента, щуо набуває актуальності у процесі загальної глобалізації, тендениій сучасного суспільства та ролі перекладу в ньому. 


\section{Ukrainian sense. 2020. ISSN 2313-4437}

Ключові слова: вирішення проблем, прочес перекладу, стратегії перекладу, SL, TL. Abstract

The background of the article are the aspects of the problem solving in the process of translation, as well as the aspect of cognitive metaphor translation Theoretical background goes to the works dedicated to intersemiotic translation of the comics, particularly the comic book "Aius. El Destino de Numancia (Ayus. The Destiny of Numantia)" from Spanish into Russian.

The purpose of the article is to discuss problem of equivalency characterized in general terms of the theory and practice of translation.

The research material has been specified with the methods of description and analytical observation of the process of problem solving in the translation process.

Results. The material of the article is the original book and the original published translation of Spanish comics based on the Numantia real story, historical fight against Roman expansion led by ancient people of Numantia, modern territory of Castille and Leon, Spain. The difficulties of translation, mainly, stylistic, cognitive, cultural conflicts in the process of translating are discussed and analyzed.Based on the identified typological characteristics, types, components, functions of the source language, the most commonly used problem solving model has been constructed and most usable translation strategies are highlighted, as well as there were recommended solutions to emerging problems of the lacunarity concept problem solving, complex asymmetric constructions translation solutions.

Discussion. The emotional-cognitive component, the value of intercultural adaptation, in the framework of heuristic theory in the process of further developing of the theory and practice of professional translation was substantiated. It has been outlined the perspectives of the current study with a cognitive component included, gaining relevance in the process of general globalization and trends of modern society as well as the role of the translation in it.

Keywords: problem solving, translation process, translation strategies, SL, TL. 